\title{
PARA UMA CRÍTICA À TESE DA CONSTITUCIONALIZAÇÃO SIMBÓLICA
}

\section{TO A CRITIQUE OF THE SYMBOLIC CONSTITUTIONALIZATION THESIS}

\section{PARA UNA CRÍTICA A LA TESIS DE LA CONSTITUCIONALIZACIÓN SIMBÓLICA}

\author{
DAVID FRANCISCO LOPES GOMES \\ Doutor, mestre e bacharel em Direito pela Universidade Federal de Minas Gerais (UFMG). Professor Adjunto do \\ Departamento de Direito do Trabalho e Introdução ao Estudo do Direito da Faculdade de Direito da Universidade \\ Federal de Minas Gerais (UFMG). Belo Horizonte, Minas Gerais, Brasil. \\ http://lattes.cnpq.br/1828373618919886 / http://orcid.org/0000-0003-0948-586 / davidflgomes@yahoo.com
}

\begin{abstract}
RESUMO
Este artigo aborda a tese da "constitucionalização simbólica” de Marcelo Neves, desde sua formulação original nos anos 1990 até suas reflexões contemporâneas. O principal propósito é demonstrar que essa tese contém contradições internas que a tornam insustentável. Para tanto, primeiramente é apresentada em detalhes a arquitetura conceitual da tese da "constitucionalização simbólica". Em seguida, as contradições internas dessa tese no livro que lhe é homônimo e no qual ela foi primeiramente apresentada são expostas. Finalmente, é discutido como o tema da "constitucionalização simbólica" permanece em trabalhos posteriores de Marcelo Neves, como "Entre Têmis e Leviatã", "Transconstitucionalismo" e "Ideias em Outro Lugar". A conclusão é no sentido de que os déficits da tese da "constitucionalização simbólica" apontam para a necessidade de uma abordagem concorrente, a ser desenvolvida em trabalhos futuros. De um ponto de vista metodológico, a pesquisa que subjaz ao presente artigo é basicamente uma pesquisa bibliográfica.
\end{abstract}

Palavras-chave: Constitucionalização Simbólica; Crítica; Marcelo Neves.

\begin{abstract}
This paper approaches the "symbolic constitutionalization" thesis by Marcelo Neves, from its original formulation in the 1990 s to its contemporary reflections. The main purpose is to demonstrate that this thesis contains internal contradictions that make it untenable. To do so, at first the conceptual architecture of "symbolic constitutionalization" thesis is presented in detail. Next, the internal contradictions of it - in the book with the same name of the thesis, in which it was initially presented - are exposed. Finally, it is discussed how the issue of the "symbolic constitucionalization" remains in the later works of Marcelo Neves, like "Entre Têmis e Leviatã", "Transconstitucionalismo" and "Ideias em Outro Lugar". The conclusion is that the deficits of the "symbolic constitutionalization" thesis point to the necessity of a concurrent approach to be developed further. From a metodological point of view, this paper presents a bibliographical research.
\end{abstract}

Keywords: Symbolic Constitutionalization; Critique; Marcelo Neves.

\section{RESUMEN}

Este artículo aborda la tesis de la "constitucionalización simbólica" de Marcelo Neves, desde su formulación original en los años 1990 hasta sus reflexiones contemporáneas. El principal propósito es demostrar que esta tesis contiene contradicciones internas que la hacen insostenible. Para ello, primero se presenta en detalle la arquitectura conceptual de la tesis de la "constitucionalización simbólica". A continuación, las contradicciones internas de esa tesis en el libro que le es homónimo y en el que fue presentada por primera vez se exponen. Finalmente, se discute cómo el tema de la "constitucionalización simbólica" permanece en trabajos posteriores de Marcelo Neves, como "Entre Témis y Leviatán", "Transconstitucionalismo" y "Ideas en Otro Lugar". La conclusión es que los déficit de la tesis de la "constitucionalización simbólica" apuntan a la necesidad de un enfoque concurrente, que se desarrollará en futuros trabajos. Desde un punto de vista metodológico, la investigación que subyace al presente artículo es básicamente una investigación bibliográfica.

Palabras clave: Constitucionalización Simbólica; Crítica; Marcelo Neves. 


\section{SUMÁRIO}

INTRODUÇÃO; 1 A ARQUITETURA CONCEITUAL DA TESE DA "CONSTITUCIONALIZAÇÃO SIMBÓLICA"; 2 AS CONTRADIÇÕES DA TESE DA "CONSTITUCIONALIZAÇÃO SIMBÓLICA" E SEU CAMINHO DE AUTOIMPLOSÃO; 3 AINDA NO MARCO REFLEXIVO DA TESE DA "CONSTITUCIONALIZAÇÃO SIMBÓLICA"; CONCLUSÃO; REFERÊNCIAS.

\section{INTRODUÇÃO ${ }^{1}$}

Marcelo Neves é, indiscutivelmente, uma das expressões de maior profundidade e rigor teóricos no direito constitucional brasileiro. No horizonte de sua produção bibliográfica, um dos tópicos de maior destaque diz respeito ao conceito de "constitucionalização simbólica", inicialmente apresentado ao público brasileiro na tese defendida em concurso para professor titular de Teoria Geral do Estado na Universidade Federal de Pernambuco, em 1992, e posteriormente publicada como livro².

Partindo da constatação da relevância dessa tese para a discussão teórico-constitucional brasileira, o objetivo do presente artigo é resgatar os elementos que compõem sua arquitetura conceitual e explicitar em que sentido, não obstante sua relevância e sua densidade, o conceitotese de "constitucionalização simbólica” contém internamente uma série de contradições que, de dentro de si mesmo, tornam-no insustentável.

Para tanto, nas páginas abaixo, em primeiro lugar são apresentados os elementos indispensáveis para a compreensão conceitual da tese da "constitucionalização simbólica". Em seguida, são trabalhadas as contradições que derivam internamente desses elementos e da articulação entre eles. Por fim, é demonstrado como, em textos posteriores àquele correspondente à tese de 1992, Marcelo Neves altera sua abordagem em pontos fundamentais, fazendo ainda mais agudas as contradições já anteriormente presentes.

\footnotetext{
${ }^{1} \mathrm{O}$ presente artigo corresponde ao capítulo $\mathrm{V}$ de tese de doutoramento, defendida junto ao Programa de Pós-Graduação em Direito da UFMG, sob orientação do professor Marcelo Andrade Cattoni de Oliveira e com bolsa CAPES: GOMES, David F. L. Gomes. A Constituição de 1824 e o problema da Modernidade: o conceito moderno de Constituição, a história constitucional brasileira e a teoria da Constituição no Brasil. Belo Horizonte: UFMG, 2016. Tese (doutorado) - Programa de Pós-Graduação em Direito, Universidade Federal de Minas Gerais, 2016. Uma primeira versão deste texto foi apresentada e discutida na disciplina Temas de Teoria da Constituição, ministrada pelo professor Bernardo Gonçalves Fernandes, no primeiro semestre de 2013.

${ }^{2}$ NEVES, Marcelo. A constitucionalização simbólica. São Paulo: Martins Fontes, 2007.
} 
Dada essa exposição panorâmica da estrutura do texto, bem como conhecido o problema sobre o qual se debruça e o objetivo que se propõe, o caminho metodológico que aqui se impõe é, por suposto, o de uma pesquisa estritamente bibliográfica.

\section{A ARQUITETURA CONCEITUAL DA TESE DA "CONSTITUCIONALIZAÇÃO SIMBÓLICA"}

Marcelo Neves começa buscando delimitar seu objeto. Para tanto, um primeiro passo lógico é a definição daquilo que será por ele trabalhado como "simbólico". Após discutir a ambiguidade dos termos "símbolo", "simbólico" e "simbolismo" e as variadas interpretações que tais termos receberão em diferentes tradições teóricas, M. Neves propõe uma "delimitação semântica", apoiada principalmente em Joseph Gusfield:

Em contraposição à atitude expressiva e semelhantemente à ação instrumental, a postura simbólica não é caracterizada pela imediaticidade da satisfação das respectivas necessidades e se relaciona com o problema da solução de conflito de interesses. Diferentemente das variáveis instrumentais, a atitude simbólica não é orientada conforme uma relação linear de meio-fim e, por outro lado, não se caracteriza por uma conexão direta e manifesta entre significante e significado, distinguindo-se por seu sentido mediato e latente. (...) o agir simbólico é conotativo na medida em que ele adquire um sentido mediato e impreciso que se acrescenta ao seu significado imediato e manifesto, e prevalece em relação a esse. $^{3}$

O passo lógico seguinte será a definição de "legislação simbólica”. Distinta da "política simbólica”, do "direito simbólico" e dos "rituais e mitos políticos e jurídicos”, ela "aponta para o predomínio, ou mesmo hipertrofia, no que se refere ao sistema jurídico, da função simbólica da atividade legiferante e do seu produto, a lei, sobretudo em detrimento da função jurídicoinstrumental"4. Ou seja, "pode-se definir a legislação simbólica como produção de textos cuja referência manifesta à realidade é normativo-jurídica, mas que serve, primária e hipertroficamente, a finalidades políticas de caráter não especificamente normativo-jurídico" ${ }^{\text {, }}$ de modo que a "referência deôntico-jurídica de ação e texto à realidade torna-se secundária, passando a ser relevante a referência político-valorativa ou 'político-ideológica'”6.

\footnotetext{
${ }^{3}$ NEVES, Marcelo. A constitucionalização simbólica. São Paulo: Martins Fontes, 2007. p. 22-23.

4 Ibidem. p. 23.

${ }^{5}$ Ibidem. p. 30.

${ }^{6}$ Ibidem. p. 31.
} 
Essa “legislação simbólica”, em sentido amplo, abrange três tipos principais, que Marcelo Neves apresenta com base em modelo de Harald Kindermann: “legislação simbólica” como "confirmação de valores sociais”; “legislação simbólica” como “legislação-álibi”, isto é, como legislação elaborada para tentar reforçar a confiança na capacidade de ação dos sistemas político e jurídico estatais, portanto, "para satisfazer as expectativas dos cidadãos, sem que com isso haja o mínimo de condições de efetivação das respectivas normas"; e "legislação simbólica" como "fórmula de compromisso dilatório"7.

$\mathrm{Na}$ sequência da tipologia assim esboçada, é preciso discriminar os "efeitos da legislação simbólica”. Antes, porém, faz-se necessário diferenciar os conceitos de "eficácia” e de "efetividade":

pode-se afirmar que a eficácia diz respeito à realização do "programa condicional," ou seja, à concreção do vínculo "se-então" abstrata e hipoteticamente previsto na norma legal, enquanto a efetividade se refere à implementação do "programa finalístico" que orientou a atividade legislativa, isto é, à concretização do vínculo "meio-fim" que decorre abstratamente do texto legal. ${ }^{8}$

Essa diferenciação permite a M. Neves especificar melhor o que compreende por “legislação simbólica":

A legislação simbólica é caracterizada por ser normativamente ineficaz, significando isso que a relação hipotético-abstrata "se-então" da "norma primária" e "da norma secundária" (programa condicional) não se concretiza regularmente. Não é suficiente a não-realização do vínculo instrumental "meiofim" que resulta abstratamente do texto legal (programa finalístico) para que venha a discutir-se sobre a função hipertroficamente simbólica de uma lei. Sendo eficaz, ou seja, regularmente observada, aplicada, executada ou usada (concretização normativa do texto legal), embora inefetiva (não-realização dos fins), não cabe falar de legislação simbólica. ${ }^{9}$

Para que essa compreensão esteja perfeita, todavia, falta lidar diretamente com o problema dos "efeitos da legislação simbólica":

A legislação simbólica não se delineia, quanto aos efeitos, tão-somente em um sentido negativo: falta de eficácia normativa e vigência social. Há atos de legislação e textos normativos que têm essas características, sem que desempenhem nenhuma função simbólica. (...) A legislação simbólica define-se

\footnotetext{
${ }^{7}$ NEVES, Marcelo. A constitucionalização simbólica. São Paulo: Martins Fontes, 2007. p. 33-42.

8 Ibidem. p. 47-48.

${ }^{9}$ Ibidem. p. 51.
} 
também num sentido positivo: ela produz efeitos relevantes para o sistema político, de natureza não especificamente jurídica. ${ }^{10}$

Definido o conceito de "legislação simbólica", o terceiro e último passo lógico para que o objeto de $M$. Neves esteja suficientemente recortado é a contraposição entre "legislação simbólica" e "constitucionalização simbólica":

A constitucionalização simbólica vai diferenciar-se da legislação simbólica pela sua maior abrangência nas dimensões social, temporal e material. Enquanto na legislação simbólica o problema se restringe a relações jurídicas de domínios específicos, não sendo envolvido o sistema jurídico como um todo, no caso da constitucionalização simbólica esse sistema é atingido no seu núcleo, comprometendo-se toda a sua estrutura operacional. ${ }^{11}$

Ainda no âmbito dessa contraposição, M. Neves transpõe, em um primeiro momento, a tipologia da “legislação simbólica” para o plano conceitual da “constitucionalização simbólica”:

pode-se classificar também a constitucionalização simbólica em três formas básicas de manifestação: 1) a constitucionalização simbólica destinada à corroboração de determinados valores sociais; 2) a Constituição como fórmula de compromisso dilatório; 3) a constitucionalização-álibi. ${ }^{12}$

Mas, analisando-os mais de perto e rejeitando os dois primeiros casos como hipóteses, a rigor, de "constitucionalização simbólica", ele conclui:

restrinjo a questão da constitucionalização simbólica aos casos em que a própria atividade constituinte (e reformadora), o texto constitucional e o discurso a ele referente funcionam, antes de tudo, como álibi para os legisladores constitucionais e governantes (em sentido amplo), como também para detentores de poder não integrados formalmente na organização estatal. ${ }^{13}$

Em síntese, a "constitucionalização simbólica" coincidiria com a "constitucionalizaçãoálibi”. A clareza e a rigidez dessas e de outras definições irão dando espaço a afirmações mais turvas e mais flexíveis ao longo tanto de "A constitucionalização simbólica" quanto de outras obras de Marcelo Neves. Por ora, contudo, elas se oferecem como um ponto de partida útil para seguir-se adiante.

$\mathrm{Na}$ verdade, sendo fiel ao percurso que $\mathrm{M}$. Neves mesmo desenvolve, cabe, antes, recuar, para refazer o caminho teórico que o levará às definições acima em torno da “constitucionalização simbólica” no livro homônimo. Inicialmente, M. Neves chama a atenção

\footnotetext{
${ }^{10}$ NEVES, Marcelo. A constitucionalização simbólica. São Paulo: Martins Fontes, 2007. p. 53.

11 Ibidem. p. 99.

12 Ibidem. p. 102.

13 Ibidem. p. 103-104.
} 
para a plurivocidade do termo “Constituição" e propõe-se a tarefa de "uma abordagem preliminar a respeito da discussão tradicional sobre os conceitos de Constituição e suas variações históricas" ${ }^{\prime 4}$. Tal tarefa é dada por cumprida com uma breve história semântica que vai de Aristóteles até o debate interno à República de Weimar ${ }^{15}$, abrindo espaço para que um conceito mais preciso de Constituição seja delineado. Numa circularidade metodologicamente arriscada, esse conceito é internamente dependente do conceito correlato de "constitucionalização":

Ao emprego do termo "constitucionalização" subjaz a ideia de que nem toda ordem jurídico-política estatalmente organizada possui uma Constituição ou, mais precisamente, desenvolveu satisfatoriamente um sistema constitucional. 0 conceito de Constituição assume, então, um significado bem delimitado. Referese à Constituição em sentido moderno. ${ }^{16}$

Quanto a esse sentido moderno, M. Neves filia-se à teoria sistêmica de Niklas Luhmann para expressá-lo: Constituição corresponde a um acoplamento estrutural entre direito e política, apresentando-se como “via de 'prestações' recíprocas, e, sobretudo, como mecanismo de interpenetração (ou mesmo de interferência) entre dois sistemas sociais autônomos"17.

M. Neves, entretanto, não se restringe a essa definição:

Não só como acoplamento estrutural entre política e direito pode ser conceituada a Constituição em uma perspectiva da teoria dos sistemas. É possível concebê-la, sob o ponto de vista político-sociológico, como um instituto específico do próprio sistema político. Mas, para os fins a que me proponho, a análise do significado da constitucionalização simbólica, apresenta-se estrategicamente oportuno o conceito de Constituição como subsistema do sistema jurídico (direito constitucional). ${ }^{18}$

Tomada a Constituição como subsistema do sistema jurídico, três questões são levantadas:

(1) Qual o significado da Constituição (moderna) para o sistema jurídico, ou, mais especificamente, para a positivação do direito? (2) Que função social preenche o direito constitucional positivo? (3) como o subsistema constitucional põe o direito positivo em relação com as exigências dos outros sistemas sociais? ${ }^{19}$

\footnotetext{
${ }^{14}$ NEVES, Marcelo. A constitucionalização simbólica. São Paulo: Martins Fontes, 2007. p. 56.

${ }^{15}$ Ibidem. p. 56-64.

${ }^{16}$ Ibidem. p. 64-65.

17 Ibidem. p. 65-66.

18 Ibidem. p. 67.

${ }^{19}$ Ibidem. p. 68.
} 
Em face da primeira questão, a Constituição é entendida como "mecanismo de autonomia operacional do direito" 20 . Sendo o direito um sistema social dentre outros, todos esses outros aparecem a ele como ambiente. 0 direito diferencia-se dos outros sistemas por seu código binário preferencial próprio - a saber, o código lícito/ilícito. Para que essa diferenciação possa resultar na autonomia do direito como sistema funcionalmente diferenciado, porém, é necessário que esse código seja aplicado também à produção do direito, à produção das normas que o compõem. A Constituição propicia essa autonomia ao definir, por meio da hierarquia entre ela e as demais normas legais, quais são aquelas que passam pelo crivo da licitude/ilicitude que, nesse nível, é o crivo da constitucionalidade/inconstitucionalidade. Com isso, o direito pode reproduzir-se de maneira autorreferencial, com base na aplicação a si de seu próprio código binário. Ao mesmo tempo, operacional e normativamente fechado, o direito pode abrirse cognitivamente a seu ambiente, recebendo interferência de outros sistemas sociais - como a economia, a moral, a religião - sem perder sua autonomia, posto que as informações advindas desses outros sistemas somente adentram o sistema jurídico nos termos do código binário deste.

Sobre a segunda questão, a função social, em sentido estrito, da Constituição e do direito constitucional positivo é descrita como sendo a de institucionalizar os direitos fundamentais e assegurar o Estado de Bem-Estar Social ${ }^{21}$. Com a institucionalização dos direitos fundamentais, a Constituição permite uma diferenciação social adequada, com o "livre desenvolvimento da comunicação (e da personalidade) conforme diversos códigos diferenciados”22, cada qual típico de um sistema social funcionalmente distinto. Por seu turno, o Estado de Bem-Estar Social, com sua atuação compensatória e distributiva, possibilita a inclusão generalizada da população naqueles variados sistemas sociais.

No que tange à terceira questão, $M$. Neves resume-se, nessa parte de sua obra, a discutir as prestações do direito constitucional ao sistema da política. Essas prestações consistiriam na "regulação jurídico-constitucional do procedimento eleitoral”23, na institucionalização da divisão de poderes e, como seu corolário, na separação entre política e administração ${ }^{24}$.

\footnotetext{
${ }^{20}$ NEVES, Marcelo. A constitucionalização simbólica. São Paulo: Martins Fontes, 2007. p. 69-74.

${ }^{21}$ Ibidem. p. 74-80.

22 Ibidem. p. 75.

${ }^{23}$ Ibidem. p. 78-80.

24 Ibidem. p. 80-83.
} 
ISSN 1981-3694

(DOI): $10.5902 / 1981369424821$

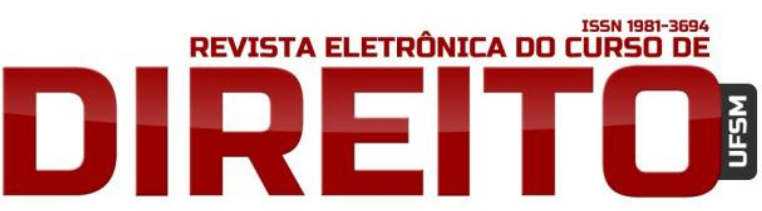

PARA UMA CRÍTICA À TESE DA CONSTITUCIONALIZAÇÃO SIMBÓLICA

DAVID FRANCISCO LOPES GOMES

Feitas essas considerações, M. Neves dirige-se para a relação entre "texto constitucional e realidade constitucional” ${ }^{25}$. Dois pilares teóricos são fundamentais para essa clivagem, que ele procura distinguir da velha dicotomia entre norma e realidade constitucional: Friedrich Müller e Peter Häberle.

Para F. Müller ${ }^{26}$, a norma jurídica é composta do programa normativo, referente aos dados linguísticos relevantes para um caso, e do âmbito normativo, referente aos dados reais relevantes do caso. Da articulação entre programa normativo e âmbito normativo surge a concretização da norma jurídica: “A norma jurídica, especialmente a norma constitucional, é produzida no decorrer do processo de concretização"27. Daí, M. Neves saca a conclusão que mais diretamente lhe interessa:

Se o âmbito normativo, que importa uma função seletiva perante os âmbitos da matéria e do caso, não se constitui de forma suficiente, a normatividade do respectivo texto constitucional é prejudicada. Faltam, então, as condições e os pressupostos para a "produção" da norma jurídica (...) e, portanto, da norma de decisão. ${ }^{28}$

Em outras palavras, são os aspectos da realidade - abrangidos pelo conceito mülleriano de "âmbito normativo" - o principal empecilho para a normatividade do texto constitucional.

Em P. Häberle ${ }^{29}$, M. Neves busca a ideia de uma interpretação da Constituição segundo a qual esse processo interpretativo inclui potencialmente órgãos estatais, poderes públicos, cidadãos e grupos sociais: “De acordo com essa abordagem, pode-se afirmar: o texto constitucional só obtém a sua normatividade mediante a inclusão do público pluralisticamente organizado no processo interpretativo, ou melhor, no processo de concretização constitucional”30.

Unindo os dois pilares, de um lado, a realidade constitucional é o obstáculo à normatividade do texto constitucional e, de outro, essa normatividade depende de um público ativo, engajado na interpretação constitucional de que resulta a concretização das normas constitucionais. Esses dois elementos - realidade constitucional e público ativo - irão aos poucos

\footnotetext{
${ }^{25}$ NEVES, Marcelo. A constitucionalização simbólica. São Paulo: Martins Fontes, 2007. p. 83-90.

${ }^{26}$ MÜLLER, Friedrich. Teoria estruturante do direito. Trad. Peter Naumann e Eurides Avance de Souza. São Paulo: Revista dos Tribunais, 2008.

${ }^{27}$ NEVES, Marcelo. A constitucionalização simbólica. São Paulo: Martins Fontes, 2007. p. 85.

${ }^{28}$ Ibidem. p. 85. Destaques do original.

29 HÄBERLE, Peter. Hermenêutica constitucional: a sociedade aberta dos intérpretes da constituição: contribuição para a interpretação pluralista e procedimental da constituição. Trad. Gilmar Ferreira Mendes. Porto Alegre: Sergio Antonio Fabris Editor, 1997.

${ }^{30}$ NEVES, Marcelo. A constitucionalização simbólica. São Paulo: Martins Fontes, 2007. p. 86.
} 
se revelando centrais para a compreensão adequada e para a crítica da tese da “constitucionalização simbólica". Por enquanto, o que importa é que, depois de invocar $F$. Müller e P. Häberle e de oferecer uma curta abordagem de ambos os modelos teóricos à luz da distinção semiótica entre sintática, semântica e pragmática ${ }^{31}, M$. Neves apresenta as duas faces de seu conceito-tese:

Da exposição sobre a relação entre texto constitucional e realidade constitucional, pode-se retirar um primeiro elemento caracterizador da constitucionalização simbólica, o seu sentido negativo: o fato de que o texto constitucional não é suficientemente concretizado normativo-juridicamente de forma generalizada. ${ }^{32}$

A esse sentido negativo agrega-se um sentido positivo:

Embora do ponto de vista jurídico a constitucionalização simbólica seja caracterizada negativamente pela ausência de concretização normativa do texto constitucional, ela também tem um sentido positivo, na medida em que a atividade constituinte e a linguagem constitucional desempenham um relevante papel político-ideológico. ${ }^{33}$

Para que não haja mal-entendidos, esse sentido positivo só pode ser assim chamado com muitas ressalvas e dentro da definição de "positivo" com que trabalha M. Neves. Afinal,

o sentido positivo da constitucionalização simbólica está vinculado à sua característica negativa (...).Sua definição engloba esses dois momentos: de um lado, sua função não é regular as condutas e orientar expectativas conforme as determinações jurídicas das respectivas disposições constitucionais; mas, de outro lado, ela responde a exigências e objetivos políticos concretos. ${ }^{34}$

É apenas ao término desse longo percurso que M. Neves explicita a contraposição entre “legislação simbólica" e "constitucionalização simbólica" tratada acima como terceiro e definitivo passo lógico no recorte metodológico de seu objeto.

A partir de então, com esse objeto suficientemente recortado, M. Neves pode explorar as tensões, produtivas ou não, a seu redor. Sua preocupação passa a ser a de distinguir o corpus teórico que envolve a "constitucionalização simbólica" de outras abordagens das quais ela se aproxima, mas com as quais ela não se confunde nem se pode confundir. Dessas distinções, a

\footnotetext{
${ }^{31}$ NEVES, Marcelo. A constitucionalização simbólica. São Paulo: Martins Fontes, 2007. p. 86-90.

32 Ibidem. p. 90-91.

33 Ibidem. p. 95.

34 Ibidem. p. 96.
} 
ISSN 1981-3694

(DOI): $10.5902 / 1981369424821$

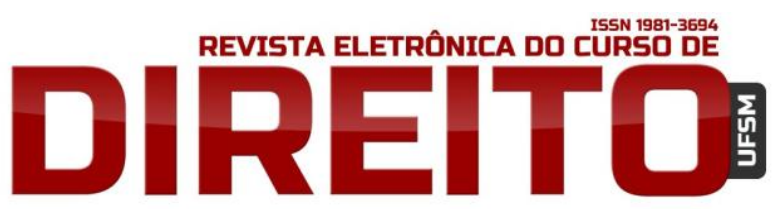

PARA UMA CRÍTICA À TESE DA CONSTITUCIONALIZAÇÃO

SIMBÓLICA

DAVID FRANCISCO LOPES GOMES

que me parece crucial é a que contrapõe a "constitucionalização simbólica” à “classificação ontológica das Constituições” ${ }^{35}$, elaborada por Karl Loewenstein ${ }^{36}$.

0 modelo loewensteiniano é exposto do seguinte modo:

Conforme sua relação com a realidade do processo de poder, as Constituições foram classificadas por Loewenstein em três tipos básicos: "normativas", "nominalistas" e "semânticas". As Constituições "normativas" seriam aquelas que direcionam realmente o processo de poder, de tal maneira que as relações políticas e os agentes de poder ficam sujeitos às suas determinações de conteúdo e ao seu controle procedimental. As Constituições "nominalistas", apesar de conterem disposições de limitação e controle da dominação política, não teriam ressonância no processo real de poder, inexistindo suficiente concretização constitucional. Já as Constituições "semânticas" seriam simples reflexos da realidade do processo político, servindo, ao contrário das "normativas", como mero instrumento dos "donos do poder", não para sua limitação ou controle. ${ }^{37}$

À primeira vista, as Constituições “nominalistas” de K. Loewenstein teriam por referência fenômenos semelhantes àqueles abrangidos pela "constitucionalização simbólica". $M$. Neves, no entanto, apressa-se em matizar essa semelhança:

O problema surge no âmbito das "Constituições nominalistas". Nela há uma discrepância radical entre práxis do poder e disposições constitucionais, um bloqueio político da concretização constitucional, obstaculizador da autonomia do sistema jurídico. (...) Nas "Constituições nominalistas" (...) ocorre o bloqueio generalizado do seu processo concretizador, de tal maneira que o texto constitucional perde relevância normativo-jurídica diante das relações de poder. Faltam os pressupostos sociais para a realização de um possível conteúdo normativo (resultado da concretização) a partir do texto constitucional. Loewenstein acentua esse aspecto negativo, apontando para a possibilidade de evolução política no sentido da realização do modelo constitucional (...). Não se apercebe, assim, da função simbólico-ideológica das "Constituições nominalistas". Ao contrário, aponta para a esperança de realização futura da Constituição, fundada na boa vontade dos detentores e destinatários do poder. E, no sentido positivo, atribui-se às "Constituições nominalistas" uma função primariamente educativa. ${ }^{38}$

\footnotetext{
${ }^{35}$ As outras distinções dão-se em face das "Constituições ritualistas", nos termos da formulação de BrunOtto Bryde; das "normas constitucionais programáticas", segundo modelo de classificação das normas constitucionais que remonta a José Afonso da Silva; do "agir comunicativo" habermasiano; e das noções de "lealdade das massas" e de "regras do silêncio", discutidas no horizonte do Estado de Bem-Estar Social da Europa Ocidental e de parte da América do Norte. Em nenhum desses casos há tantas dificuldades para que se possa diferir a "constitucionalização simbólica" quanto perante a "classificação ontológica" de K. Loewenstein, sobretudo seu conceito de "Constituições nominalistas"; por isso mesmo, nenhuma outra distinção é tão reveladora dos contornos específicos do conceito-tese de M. Neves. Conferir NEVES, Marcelo. A constitucionalização simbólica. São Paulo: Martins Fontes, 2007. p. 110-126.

36 LOEWENSTEIN, Karl. Teoria de la Constitución. Trad. Alfredo Gallego Anabitarte. Barcelona: Ariel, 1976.

${ }^{37}$ NEVES, Marcelo. A constitucionalização simbólica. São Paulo: Martins Fontes, 2007. p. 105-106.

${ }^{38}$ Ibidem. p. 107.
} 
O equívoco de K. Loewenstein estaria em conceder a suas “Constituições nominalistas" uma "função educativa", enxergando nelas a esperança de que pudessem atuar como guia em direção a um futuro melhor, ao passo que M. Neves não thes atribui senão o papel políticoideológico em que reside, para ele, o "sentido positivo", acima mencionado, da “constitucionalização simbólica". Por conseguinte, se se leva a sério a arquitetura interna própria da teorização levada a cabo por K. Loewenstein, não há outra conclusão possível que não seja reconhecer que entre as “Constituições nominalistas" e a "constitucionalização simbólica” há diferenças instransponíveis, que se exacerbam na impossibilidade, diante da “constitucionalização simbólica”, de qualquer esperança quanto a sua concretização histórica, futura. ${ }^{39}$

$\mathrm{Na}$ sequência de seu texto, antes de analisar a experiência constitucional brasileira como referência exemplificativa e de se debruçar sobre o que seriam as perspectivas para o debate sobre a "constitucionalização simbólica", M. Neves aprofunda suas reflexões. Dentre elas, gostar-se-ia de destacar sobretudo dois aspectos, sem os quais a tese da "constitucionalização simbólica" não se dá a ler por completo: seu caráter alopoiético e sua definição como um problema da "modernidade periférica".

$\mathrm{Na}$ sociedade moderna funcionalmente diferenciada, cada sistema reproduz-se a partir de seu próprio código. Com isso, torna-se possível, a um só tempo, o fechamento normativo e operacional do sistema, sua abertura cognitiva ao ambiente, e, logo, a diferenciação adequada entre sistema e ambiente. Em relação ao direito, a Constituição é a estrutura que possibilita esse processo de autonomização sistêmica. Como autorreferência, isto é, como referência do sistema a si mesmo, por meio de seu código binário preferencial aplicado na produção de seus elementos, tal processo caracterizaria o direito moderno como sistema autopoiético. Contudo, dadas a ineficácia e a inefetividade constitucionais, em contextos de "constitucionalização simbólica" não se fariam presentes as condições para a autopoiese do sistema jurídico. Ao contrário, sua reprodução seria determinada por critérios, programas e códigos do ambiente,

\footnotetext{
${ }^{39}$ É importante mencionar, quanto às diferenças gerais entre o modelo classificatório loewensteiniano e a abordagem de $M$. Neves, que este propõe a seguinte alteração de nomenclatura para as "Constituições semânticas": "Em relação às 'Constituições semânticas', cabe inicialmente uma mudança de denominação, uma vez que na classificação de Loewenstein o termo 'semântico' é empregado sem quase nenhuma conexão com o seu sentido habitual, podendo contribuir para equívocos. Considerando que elas foram designadas 'instrumentos' dos detentores do poder, parece mais adequada a expressão 'Constituições instrumentalistas'." NEVES, Marcelo. A constitucionalização simbólica. São Paulo: Martins Fontes, 2007. p. 109.
} 
resultando no "problema da alopoiese como negação da auto-referência (sic) operacional do direito”: “Derivada etimologicamente do grego állos ('um outro', 'diferente') + poíesis ('produção', 'criação'), a palavra designa a (re)produção do sistema por critérios, programas e códigos do seu ambiente" 40 .

Detalhando o que entende por alopoiese do direito, M. Neves explica: “Isso significa a sobreposição de outros códigos de comunicação, especialmente do econômico (ter/não-ter) e do político (poder/não-poder), sobre o código 'lícito/ilícito', em detrimento da eficiência, funcionalidade e mesmo racionalidade do direito"41. A partir dessa compreensão, a “constitucionalização simbólica" é definida como sobreposição do sistema político ao direito ${ }^{42}$. Todavia, na medida em que a Constituição é estrutura de acoplamento entre direito e política, permitindo o fechamento autorreferencial de ambos, essa sobreposição da política ao direito, derivada da falta de concretização constitucional, não deixa intacta a autonomia também do sistema político, posto que ele não pode mais contar com as prestações do sistema jurídico. Em decorrência, a política vê-se fragilizada, suscetível a influências imediatas - não filtradas por seu código binário preferencial - advindas do ambiente, sobremaneira do sistema econômico: “Principalmente no que se refere às injunções do código "ter/não-ter" (economia), observa-se claramente a fraqueza do sistema político em situações de constitucionalismo simbólico, um problema típico do Estado periférico" ${ }^{43}$.

Esse Estado periférico é o correspondente institucional do conceito de "modernidade periférica". M. Neves reconhece as dificuldades da distinção entre "centro" e "periferia" na modernidade:

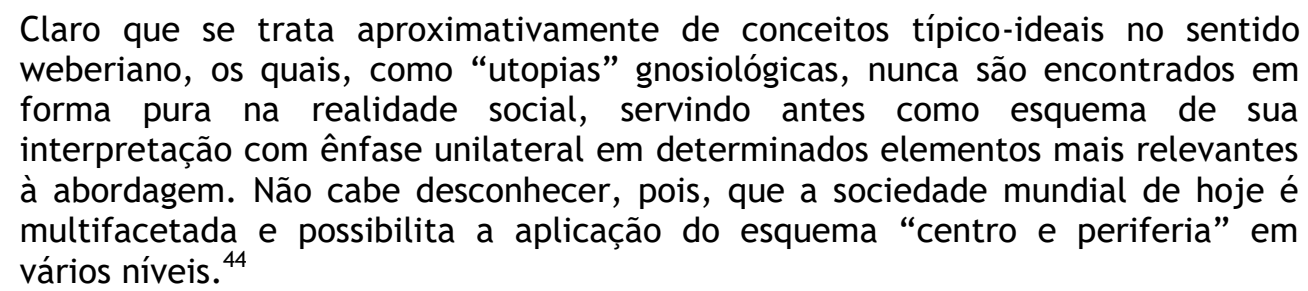

Não obstante, insiste:

\footnotetext{
${ }^{40}$ NEVES, Marcelo. A constitucionalização simbólica. São Paulo: Martins Fontes, 2007. p. 142.

41 Ibidem. p. 146.

42 Ibidem. p. 148-152.

43 Ibidem. p. 152.

44 Ibidem. p. 171.
} 


\begin{abstract}
Parece-me, porém, que a distinção entre modernidade central e periférica é analiticamente frutífera, na medida em que, definindo-se a complexidade social e o desaparecimento de uma moral imediatamente válida para todas as esferas da sociedade como características da modernidade, verifica-se que, em determinadas regiões estatalmente delimitadas (países periféricos), não houve de maneira nenhuma a efetivação adequada da autonomia sistêmica de acordo com o princípio da diferenciação funcional nem a constituição de uma esfera pública fundada na generalização institucional da cidadania, características (ao menos aparentes) de outras regiões estatalmente organizadas (países centrais). ${ }^{45}$
\end{abstract}

E, em tom categórico, afirma: "A constitucionalização simbólica como alopoiese do sistema jurídico é um problema fundamentalmente da modernidade periférica" ${ }^{46}$.

Ausência de diferenciação funcional adequada e de uma esfera pública baseada na generalização institucional da cidadania são os traços que definem a "modernidade periférica" nada mais do que, observados de outro ponto de vista metodológico, os elementos da realidade constitucional e do público ativo, enfatizados anteriormente como centrais para o entendimento e a crítica da tese da "constitucionalização simbólica".

A esta altura da exposição, uma primeira síntese é possível. Constituições modernas poderiam ser conceituadas como estruturas de acoplamento entre os sistemas do direito e da política. Como tais, elas propiciam o fechamento normativo e operacional de cada um desses sistemas, tanto quanto sua abertura cognitiva ao ambiente. Além disso, direito e política oferecem-se prestações recíprocas, cabendo destacar a função do código binário próprio ao sistema jurídico - o código lícito/ilícito - atuando como segundo código da política. Por fim, ao institucionalizarem direitos fundamentais, as Constituições modernas asseguram as condições para o livre desenvolvimento autorreferencial de outros sistemas sociais e, com as garantias do Estado de Bem-Estar Social, tornam possível a inclusão generalizada da população nesses sistemas.

A "constitucionalização simbólica" alude a situações em que há inefetividade e ineficácia generalizadas dos dispositivos textuais constitucionais, de maneira que sua dimensão técnico-jurídica é preterida frente à hipertrofia da dimensão político-ideológica. Isso significa que a "constitucionalização simbólica" não é definida apenas por seu aspecto negativo ausência de concretização constitucional -, sendo indispensável seu aspecto “positivo" - a saber, o papel político-ideológico que desempenha.

Em casos de "constitucionalização simbólica”, a diferenciação funcional entre direito e política não se realiza adequadamente. Como consequência, o direito perde sua autorreferência,

\footnotetext{
${ }^{45}$ NEVES, Marcelo. A constitucionalização simbólica. São Paulo: Martins Fontes, 2007. p. 171.

${ }^{46}$ Ibidem.
} 
ISSN 1981-3694

(DOI): $10.5902 / 1981369424821$

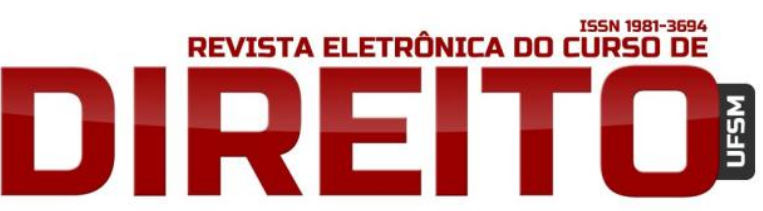

PARA UMA CRÍTICA À TESE DA CONSTITUCIONALIZAÇÃO SIMBÓLICA

DAVID FRANCISCO LOPES GOMES

passando a ser determinado por códigos oriundos do ambiente, sobrepostos ao código binário preferencial do sistema jurídico: o código lícito/ilícito perde sua função em face de outros códigos. Logo, não se trata mais de um direito autopoiético, cabendo definir a “constitucionalização simbólica” como alopoiese do direito. Essa alopoiese pode ser entendida como sobreposição da política ao direito, mas esse entendimento pode conduzir a interpretações equivocadas: a sobreposição da política ao direito é sintoma de uma diferenciação funcional precária ou ausente; em quadros como esse, o direito, fragilizado como sistema incapaz de reproduzir-se conforme seus próprios códigos, critérios e programas, não oferece as devidas prestações à política; em decorrência da falta de atuação do código lícito/ilícito como seu segundo código, o sistema político perde também ele sua capacidade de autorreferência, vindo a mostrar-se suscetível a influências diretas do ambiente, precipuamente do sistema econômico e suas injunções baseadas no código ter/não-ter.

Ao mesmo tempo, a falta de concretização constitucional impede que o direito - mais especificamente, o direito constitucional - cumpra sua função social: direitos fundamentais e Estado de Bem-Estar Social não são suficientemente assegurados. Como corolário, multiplicamse relações de subintegração - em que amplos setores da população "não têm acesso aos benefícios do ordenamento jurídico estatal, mas dependem de suas prescrições impositivas" 47 - e de sobreintegração - relativas a "grupos privilegiados que, principalmente com o apoio da burocracia estatal, desenvolvem suas ações bloqueantes da reprodução do direito" ${ }^{48}$ - resultando em subcidadãos e sobrecidadãos, mas não na universalização da "cidadania como mecanismo de integração jurídico-política igualitária da população na sociedade"49.

Esse amplo, multifacetado e complexo problema abrangido pelo conceito de “constitucionalização simbólica” estaria presente basicamente na "modernidade periférica”, marcada pela inexistência tanto de uma adequada diferenciação funcional entre os distintos sistemas sociais quanto de uma esfera pública ativa fincada numa cidadania institucionalmente generalizada. Esses dois elementos recebem, a propósito, o acento explicativo no horizonte da “constitucionalização simbólica”, isto é, eles é que são recorrentemente chamados a explicar, em último grau, o conceito-tese de Marcelo Neves. A busca de sustentação teórica em F. Müller e P. Häberle já havia mostrado o peso da realidade constitucional e do público ativo para a

\footnotetext{
${ }^{47}$ NEVES, Marcelo. Entre Têmis e Leviatã: uma relação difícil: o Estado Democrático de Direito a partir e além de Luhmann e Habermas. São Paulo: Martins Fontes, 2006. p. 248.

48 Ibidem. p. 250.

49 Ibidem. p. 248.
} 
tradução dogmática do significado crítico que ele atribui à sua elaboração teórica da “constitucionalização simbólica”. Isso fica mais nítido, entretanto, quando M. Neves a relaciona diretamente com uma "realidade constitucional desjuridificante":

A pretensa filtragem das expectativas de comportamento mediante a normatização constituinte não é seguida, de maneira alguma, da orientação generalizada das expectativas normativas com base no texto constitucional, quer dizer, não é acompanhada da generalização congruente das expectativas normativo-constitucionais. O vivenciar normativo da população em geral e dos agentes estatais faz implodir a Constituição como ordem básica da comunicação jurídica.

[...] O que há é politização desjuridificante da realidade constitucional, respaldada evidentemente nas relações econômicas. ${ }^{50}$

É essa realidade que não permite fazer coincidir a "constitucionalização simbólica" com a "Constituição nominalista" loewensteiniana, pois perante uma realidade assim retratada não parece possível, para M. Neves, manter a “esperança de realização futura da Constituição” e atribuir a ela, ainda que fosse tão-só, uma "função primariamente educativa" 51 .

Diante dessa breve síntese, as contradições escancaram-se: Constituições simbólicas são textos constitucionais carentes de concretização normativa devido à realidade constitucional desjuridificante na qual se inserem em países de "modernidade periférica". Ausentes as condições reais para a diferenciação funcional sistêmica e para a emergência de uma esfera pública autônoma e atuante, não é possível que a Constituição “constitua” algo. Se assim o é, $a$ contrario sensu, Constituições apenas poderiam gozar de eficácia e efetividade generalizadas em países nos quais a realidade constitucional já fosse suficientemente estruturada pela diferenciação funcional e por um público ativo organizado pluralisticamente. Mas não cabe à Constituição atuar exatamente como elemento dessa diferenciação funcional? Não é ela definida como estrutura de acoplamento entre o sistema jurídico e o sistema político, propiciando fechamento normativo e operacional e abertura cognitiva na relação entre sistemas e ambiente? Não é também ela quem, por meio dos direitos fundamentais e do Estado de Bem-Estar Social, institucionaliza condições de livre desenvolvimento da personalidade e da comunicação internamente aos vários sistemas sociais e implementa condições de inclusão potencialmente generalizada da população nesses sistemas?

Mas, se ela só desempenha suas funções quando suas funções são, em certo sentido, dispensáveis - em outras palavras, se ela diferencia direito e política, assim como

\footnotetext{
50 NEVES, Marcelo. A constitucionalização simbólica. São Paulo: Martins Fontes, 2007. p. 169.

51 Ibidem. p. 107.
} 
institucionaliza condições para a diferenciação de outros sistemas e para a inclusão populacional neles, somente quando os sistemas já estão suficientemente diferenciados e a desigualdade social não representa maiores problemas para uma concepção generalizante de cidadania - em que consiste o traço distintivo de uma Constituição moderna? Não teria ela perdido, pelas mãos da teoria, praticamente todo o potencial normativo e sido transformada numa mera estrutura de autodescrição de sociedades típicas de determinadas partes do mundo? Não seria, então, descartável o próprio conceito moderno de Constituição - mesmo conforme definido nos termos da teoria sistêmica - e sua expansão teórica a países de "modernidade periférica”, uma vez que essa expansão não faz mais do que comprovar a inadequação desse conceito como conceito global? Não bastaria simplesmente dizer que tais países - qualquer que seja o nome que deem aos textos legais que ostentam como topo da hierarquia juspositiva - não possuem Constituição?

\section{AS CONTRADIÇÕES DA TESE DA "CONSTITUCIONALIZAÇÃO SIMBÓLICA" E SEU CAMINHO DE AUTOIMPLOSÃO}

Tais contradições parecem não haver passado despercebidas por Marcelo Neves. Ao lidar com elas, porém, ele inelutavelmente as aprofunda, levando a arquitetura de sua teoria, bela e tenazmente construída, a um verdadeiro colapso. Três pontos principais pavimentam o caminho de autoimplosão da tese da “constitucionalização simbólica" dentro de si própria. Esses pontos já se podem vislumbrar ao longo de todo o livro homônimo, mas adquirem uma nitidez irrefragável em seus dois últimos tópicos, dedicados, respectivamente, à experiência constitucional brasileira e às perspectivas do debate sobre a "constitucionalização simbólica" para além da "modernidade periférica".

Em primeiro lugar, ao destrinchar as consequências da "constitucionalização simbólica", M. Neves aponta para o fato de que, com a hipertrofia de sua dimensão político-ideológica, não apenas as disposições do texto constitucional não são concretizadas normativamente, mas, concomitantemente, outras alternativas de transformação social - precisamente as que seriam requeridas - são impossibilitadas. Inicialmente, M. Neves diz:

Em caso de constitucionalização simbólica, o problema "ideológico" consiste no fato de que se transmite um modelo cuja realização só seria possível sob condições sociais totalmente diversas. Dessa maneira, perde-se transparência em relação ao fato de que a situação social correspondente ao modelo constitucional simbólico só poderia tornar-se realidade mediante uma profunda transformação 
da sociedade. Ou o figurino constitucional atual como ideal, que através dos "donos do poder" e sem prejuízo para os grupos privilegiados deverá ser realizado, desenvolvendo-se, então, a fórmula retórica da boa intenção do legislador constituinte e dos governantes em geral. ${ }^{52}$

Em seguida, recorrendo à expressão "Constitucionalismo aparente”, tomada de empréstimo a Dieter Grimm e utilizada como semelhante à “constitucionalização simbólica”, ele completa:

O “Constitucionalismo aparente" implica, nessas condições, uma representação ilusória em relação à realidade constitucional, servindo antes para imunizar o sistema político contra outras alternativas. Através dele, não apenas podem permanecer inalterados os problemas e relações que seriam normatizados com base nas respectivas disposições constitucionais, mas também ser obstruído o caminho das mudanças sociais em direção ao proclamado Estado constitucional. ${ }^{53}$

Paralelamente, essa dimensão político-ideológica hipertrofiada, que impede a concretização constitucional e obstaculiza o caminho para alternativas de mudança, engloba em seu círculo vicioso tanto os detentores do poder quanto seus críticos. Insistindo nas implicações semióticas de seu conceito-tese, $M$. Neves escreve:

Quanto ao modo de referência à realidade, a linguagem constitucional funciona basicamente como mecanismo de influência política, tanto na retórica dos defensores do status quo quanto no discurso dos grupos interessados em transformações efetivas na relação de poder.

[...] O texto constitucional passa fundamentalmente a ser objeto do discurso político. Pragmaticamente, perde sua força comissivo-diretiva, tornando-se fundamentalmente mecanismo de persuasão política. [...] Perlocutivamente, o discurso constitucionalista, tanto dos detentores do poder quanto dos seus críticos, não se dirige fundamentalmente no sentido de, generalizadamente, obrigar, proibir ou permitir juridicamente, constituindo antes uma linguagem destinada a persuadir e convencer politicamente $[. ..] .^{54}$

Mais à frente, valendo-se da clivagem sobrecidadania/subcidadania, complementa:

De parte dos agentes governamentais, vinculados em regra à "sobrecidadania", o discurso político aponta para a identificação do governo ou do Estado com os "valores" consagrados no documento constitucional. Sendo evidente que tais valores não encontram o mínimo de respaldo na realidade constitucional desjuridificante do presente, os agentes de poder desenvolvem a retórica de sua realização no futuro (remoto). A constitucionalização atua como álibi: o "Estado" apresenta-se como identificado com os valores constitucionais, que não se realizam no presente por "culpa" do subdesenvolvimento da "sociedade". Já na retórica dos grupos interessados em transformações reais nas relações de poder,

\footnotetext{
${ }^{52}$ NEVES, Marcelo. A constitucionalização simbólica. São Paulo: Martins Fontes, 2007. p. 98.

53 Ibidem. p. 98.

54 Ibidem. p. 164.
} 
os quais pretendem frequentemente representar a "subcidadania", invocam-se os direitos proclamados no texto constitucional para denunciar a "realidade constitucional inconstitucional" e atribuir ao Estado/governo dos "sobrecidadãos" a "culpa" pela não-realização generalizada dos direitos constitucionais, que seria possível estivesse o Estado/governo em outras mãos. A essa retórica constitucionalista subjaz muitas vezes uma concepção voluntarista e instrumentalista do direito. ${ }^{55}$

Acrescenta-se a isso a constatação de que, quanto aos subcidadãos eles mesmos - e não seus representantes envolvidos na suposta crítica ao poder e na luta pelo poder - "a Constituição apresenta-se antes como complexo de restrições oficiais corporificadas nos órgãos e agentes estatais, não como estrutura constitutiva de direitos fundamentais" ${ }^{56}$. Essa constatação específica no que diz respeito aos subcidadãos é, a propósito, uma subespécie de uma constatação mais ampla, relativa à população como um todo: afinal, os subcidadãos são simplesmente parte dessa população cujos comportamentos são "geralmente alheios aos direitos e deveres proclamados constitucionalmente" ${ }^{27}$.

Fecha-se o quadro: em contextos de "constitucionalização simbólica”, a concretização normativa constitucional é impossibilitada pela "realidade constitucional desjuridificante"; por outro lado, alternativas outras de mudança, que poderiam levar às transformações necessárias dessa realidade, são igualmente bloqueadas. Os detentores do poder e da manutenção do status quo apropriam-se retoricamente do texto constitucional e atribuem a responsabilidade por sua não efetivação à sociedade; não apenas eles, porém, tomam retoricamente a Constituição: também seus críticos o fazem, depositando a responsabilidade pela não efetivação constitucional não mais na sociedade, mas naqueles detentores dos postos de poder dentro do Estado. Como quer que seja, a população dessa sociedade - especialmente os subcidadãos, que, ao vivenciarem direta e imediatamente a situação de exclusão, poderiam voltar-se de maneira mais radical em favor das mudanças - é alheia aos direitos e deveres constitucionalmente estabelecidos.

Em resumo, frente à “constitucionalização simbólica”, há, a um só tempo, como fragmentos de um mosaico complexo, uma população sem conhecimento do que a Constituição lhes assegura, uma "realidade constitucional” que torna impossível a efetivação generalizante da Constituição, uma imunização contra as transformações sociais necessárias para alterar essa

\footnotetext{
${ }^{55}$ NEVES, Marcelo. A constitucionalização simbólica. São Paulo: Martins Fontes, 2007. p. 175-176.

56 Ibidem. p. 175.

57 Ibidem. p. 163.
} 
realidade e uma perda de sentido da crítica a tudo isso, posto que essa crítica se esvai no mesmo caldeirão retórico da hipertrofia político-ideológica.

O segundo dos três pontos que se gostaria de explorar na tentativa de esclarecer em que sentido a tese da “constitucionalização simbólica” retira de si suas próprias bases une-se umbilicalmente a essa primeira discussão.

Se o quadro completo referente à "constitucionalização simbólica" é o que ficou emoldurado nos parágrafos acima; se a "classificação ontológica” de Karl Loewenstein é tão relevante para a construção bem delimitada do que significa a "constitucionalização simbólica"; se, ademais, em países de "modernidade periférica" não há as condições sociais para a existência de "Constituições normativas" e se, por outro lado, as "Constituições nominalistas" também não se fazem presentes, uma vez que a Constituição não consegue iluminar o caminho em direção a sua realização futura, não restaria somente uma única opção para uma reestruturação social profunda: um grupo de pessoas que - ilustradas o suficiente para não se confundirem com o grosso de uma população alheia a seus direitos e deveres e para, ao mesmo tempo, não submergirem no círculo vicioso da apropriação constitucional retórica - fosse capaz de, para além da Constituição e independentemente dela, guiar messianicamente a massa ignóbil do povo rumo a uma sociedade mais bem ordenada e menos excludente? Mas não seria isso sinônimo de processos transformadores conduzidos de cima para baixo: abrindo-se mão dos eufemismos, de uma apologia inconfessa a regimes autoritários como única alternativa possível para que os países da "modernidade periférica" alcancem um patamar mais elevado de desenvolvimento e aproximem-se dos países da "modernidade central"?

Seria deslealdade afirmar que é essa apologia ao autoritarismo modernizador a mensagem secreta que se vai desvelando no texto de Marcelo Neves. Mas, se essa me parece ser, a partir do que ficou discutido até aqui, a conclusão lógica inelutável desse texto, o que me leva a afirmar a deslealdade dessa conclusão? A resposta não oferece dificuldades - M. Neves expressamente rejeita tal conclusão:

A inconsistência da "ordem constitucional" desgasta o próprio discurso constitucionalista dos críticos do sistema de dominação. Desmascarada a farsa constitucionalista, seguem-se o cinismo das elites e a apatia do público. Tal situação pode levar à estagnação política. É possível que, como reação, recorrase ao "realismo constitucional" ou "idealismo objetivo", em contraposição ao "idealismo utópico" existente. Entretanto, como ensinaram as experiências de "constitucionalismo instrumental" de 1937 e 1964, o recurso a essa semântica autoritária não implicará, seguramente, a "reconciliação do Estado com a 
realidade nacional", mas, antes, a identificação excludente do sistema jurídico estatal com as "ideologias" e interesses dos detentores eventuais do poder. ${ }^{58}$

Não obstante, se a conclusão logicamente necessária que decorre da exposição da tese da "constitucionalização simbólica" é no sentido do autoritarismo modernizador como única possibilidade de transformações sociais reais, $M$. Neves só poderá concluir de outro modo à custa de contradições que colocam radicalmente em xeque as bases anteriormente assentadas.

No último parágrafo do penúltimo capítulo do livro - capítulo dedicado ao Brasil como caso exemplificativo de "constitucionalização simbólica” - lê-se:

[...] não se deve interpretar a constitucionalização simbólica como um jogo de soma zero na luta política pela ampliação ou restrição da cidadania, equiparando-a ao "instrumentalismo condicional" das experiências autocráticas. Enquanto não estão presentes "regras do silêncio" democráticas nem ditatoriais, - contexto da constitucionalização simbólica proporciona o surgimento de movimentos e organizações sociais envolvidos criticamente na realização dos valores proclamados solenemente no texto constitucional e, portanto, integrados na luta política pela ampliação da cidadania. Sendo assim, é possível a construção de uma esfera pública pluralista que, apesar de sua limitação, seja capaz de articular-se com sucesso em torno dos procedimentos democráticos previstos no texto constitucional. ${ }^{59}$

Mas a crítica às “Constituições nominalistas" de $\mathrm{K}$. Loewenstein não se dirigia exatamente à esperança ingênua que esse conceito revelava de que em torno da Constituição processos de aprendizagem pudessem desenrolar-se e, pois, a Constituição pudesse vir a atuar como um farol que ilumina a travessia de águas turbulentas? Na recusa a qualquer espécie de esperança semelhante não residia o contraponto que $M$. Neves, por meio de seu conceito-tese de "constitucionalização simbólica”, oferecia à classificação loewensteiniana? Se a “constitucionalização simbólica" alude a contextos em que do texto constitucional não deriva a estabilização generalizada de expectativas normativas contrafáticas, posto faltarem as “condições sociais para a realização de uma Constituição inerente à democracia e ao Estado de direito" 60 , e se mesmo as críticas aos detentores do poder interessados na manutenção inalterada das mazelas sociais perdem-se na retórica político-ideológica simbologizada e simbologizante, como se pode sustentar, então, que, nesses contextos, surjam movimentos e organizações sociais empenhados "criticamente na realização dos valores proclamados solenemente no texto constitucional" e construa-se uma esfera pública pluralista em volta dos

\footnotetext{
${ }^{58}$ NEVES, Marcelo. A constitucionalização simbólica. São Paulo: Martins Fontes, 2007. p. 188. Destaques do original.

${ }^{59}$ Ibidem. p. 188-189.

60 Ibidem. p. 187.
} 
procedimentos democráticos previstos em tal texto? Não era a impossibilidade de tudo isso o que dava à "constitucionalização simbólica” seu rigor conceitual? De que serve analiticamente o conceito de "constitucionalização simbólica" se tudo aquilo que ele nega - como se fora impossível - durante a formação de seus alicerces é afirmado - como sendo possível - no arremate de seu edifício?

Marcelo Neves procura explicitamente afastar sua distinção entre texto constitucional e “realidade constitucional” da dicotomia entre norma e realidade. Esse afastamento, porém, faz sentido apenas na medida em que importa enfatizar a diferença entre texto e norma. No fundo, ressalvada essa diferença e seu uso específico, o que perpassa todo o texto de Marcelo Neves é uma separação radical entre realidade e normatividade - para falar em termos habermasianos, entre "facticidade e validade" 61 . A "realidade constitucional" é descrita como se totalmente desprovida de expectativas normativas internas, de idealidades imanentes. Acima dela, fora dela, paira um texto constitucional incapaz de produzir a partir de si concretização normativa, generalização de expectativas normativas diante dessa realidade bruta. Há, com isso, uma sobrecarga tanto de um lado quanto do outro do binômio artificialmente esboçado: a Constituição é sobrecarregada com a exclusividade da tarefa de generalizar uma normatividade que inexiste na "realidade constitucional"; esta, por seu turno, é sobrecarregada com a acusação de não restar nela nada mais do que a facticidade bruta. Assim erigido, o hiato não pode ser superado. O conceito-tese de "constitucionalização simbólica" não faz mais do que agregar dicotomicamente aquilo que metodologicamente ele separou, a saber, realidade e normatividade - dimensões que, a propósito, no mundo, não deixaram de estar sempre emaranhadas de forma tensa.

Posto que as Constituições modernas jamais são simplesmente textos fora da realidade, como - enquanto abstrações - correspondem a abstrações reais no mundo, como também são sempre a expressão formal de idealidades imanentes já presentes em maior ou menor grau no interior das sociedades que as elaboram, esse hiato metodologicamente forçado vê-se negado pelo próprio mundo, pela própria realidade: queira ou não a teoria, movimentos e organizações sociais articulam-se, lutas acontecem, conflitos exsurgem: a Constituição é objeto de disputa, é

\footnotetext{
${ }^{61}$ HABERMAS, Jürgen. Facticidad y validez - Sobre el derecho y el Estado democrático de derecho en términos de teoria del discurso. Trad. Manuel Jiménez Redondo. 4. ed. Madrid: Trotta, 2005. Para uma crítica semelhante, embora não dirigida diretamente a M. Neves, conferir CARVALHO NETTO, Menelick. Apresentação. In: MÜLLER, Friedrich. Legitimidade como conflito concreto do direito positivo. Cadernos da Escola do Legislativo, Belo Horizonte, 5 (9), p. 7-12, jul./dez. 1999; CATTONI DE OLIVEIRA, Marcelo Andrade. Teoria da Constituição. Belo Horizonte: Initia Via, 2012; REPOLÊS, Maria Fernanda Salcedo. Habermas e a Desobediência Civil. Belo Horizonte: Mandamentos, 2003.
} 
ISSN 1981-3694

(DOI): $10.5902 / 1981369424821$

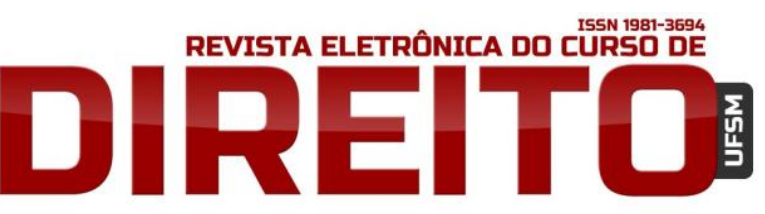

PARA UMA CRÍTICA À TESE DA CONSTITUCIONALIZAÇÃO SIMBÓLICA

DAVID FRANCISCO LOPES GOMES

plataforma para cobrança de promessas que ela mesma consubstancializa, é também ferramenta de batalha, é ainda garantia de conquistas, tanto quanto possibilidade de futuro. Negar que isso aconteça é negar um universo empírico que se escancara cotidianamente ${ }^{62}$; reconhecer que isso aconteça, por outro lado, é inevitavelmente contradizer o que se definira como “constitucionalização simbólica”, aprofundá-la em sua senda de autoimplosão.

O terceiro e último elemento dessa senda diz respeito à definição da “constitucionalização simbólica" como "problema fundamentalmente da modernidade periférica":

As exposições precedentes partiram da premissa de que predominou uma bifurcação da sociedade mundial moderna em centro e periferia, de tal maneira que a constitucionalização simbólica - diferentemente da legislação simbólica pôde ser caracterizada como um problema específico da modernidade periférica. Agora, entretanto, cabe questionar se os recentes desenvolvimentos da sociedade mundial não levarão a um quadro em que o problema da constitucionalização simbólica estender-se-á aos Estados da modernidade central. Essa possibilidade está relacionada com a tendência a uma periferização paradoxal do centro. ${ }^{63}$

Essa "periferização do centro" derivaria da expansão hipertrófica do sistema econômico, com seu código binário preferencial, sobre os outros sistemas, particularmente o político e o jurídico, no plano global. Como resultado, "as Constituições dos Estados democráticos e sociais de direito podem perder intensamente normatividade jurídica no contexto da 'globalização econômica' e, com isso, tornar-se Constituições (hipertroficamente) simbólicas" ${ }^{64}$. Ou seja,

não se deve excluir a possibilidade (...) de que, no contexto de uma "globalização econômica", radical, isto é, da economização da sociedade mundial suceda uma propagação incontrolada da "exclusão" primária sobre os países centrais, até o momento ainda estruturados no regime de bem-estar, implicando a fragilização ou a substituição da diferença "centro/periferia" fundada na economia e possibilitada por força da segmentação da sociedade mundial em Estados - mediante a fortificação da diferença "exclusão/inclusão" no plano global (...). ${ }^{65}$

Mas não havia sido afirmado o valor analítico da clivagem "centro/periferia", muito embora reconhecidas as dificuldades nela implicadas? Não era essa clivagem um dos elementos

\footnotetext{
${ }^{62}$ Em relação a este ponto, $M$. Neves passa ao largo de todo o debate contemporâneo internamente às ciências sociais. Conferir, por exemplo, o volume 84 da Revista "Lua Nova": LUA NOVA. Lua Nova: Revista de Cultura Política. v. 84 - Após a Participação. São Paulo: CEDEC, 2011.

${ }^{63}$ NEVES, Marcelo. A constitucionalização simbólica. São Paulo: Martins Fontes, 2007. p. 191.

${ }^{64}$ Ibidem. p. 196.

${ }^{65}$ Ibidem. p. 200.
} 
que, por contraposição entre características das sociedades do "centro" e sociedades da "periferia”, tornava mais palpável o conceito-tese de “constitucionalização simbólica”? Em que sentido aquela relevância analítica pode ainda ser justificada na medida em que, pouco depois, ela aparece relativizada? A “constitucionalização simbólica”, que tinha por referência processos distintos dos abrangidos pelas "Constituições nominalistas", mas que, no fim, poderia dar lugar a processos semelhantes, é também definida como algo típico da "modernidade periférica", mas que, no fim, pode vir a ser igualmente encontrado na "modernidade central"? O que resta do conceito-tese de "constitucionalização simbólica" quando alguns dos traços que lhe dão seu contorno fundamental tornam-se borrados a tal ponto que não é mais possível enxergá-los com um mínimo de clareza?

0 que resta é a constatação de que, internamente ao conceito-tese de “constitucionalização simbólica”, já estão postas as contradições que revelam sua insustentabilidade e forçam sua implosão. Logo, tentar enfrentar essas contradições permanecendo dentro dos limites conceituais da “constitucionalização simbólica" é, inescapavelmente, recrudescer a força dessas contradições e agudizar a agonia desse conceitotese.

\section{AINDA NO MARCO REFLEXIVO DA TESE DA "CONSTITUCIONALIZAÇÃO SIMBÓLICA"}

M. Neves insistirá tanto nesse conceito-tese quanto nos elementos que o formam em textos posteriores àquele correspondente à tese de 1992, mesmo quando os problemas em torno da "constitucionalização simbólica" tiverem uma importância secundária diante de outros problemas tratados em primeiro plano ${ }^{66}$. Poucas serão as alterações em sua concepção. Algumas destas, porém, merecem destaque, principalmente por iluminarem, por outros ângulos, as contradições em que se enreda a tese da "constitucionalização simbólica”.

Em “Entre Têmis e Leviatã” - Livro dedicado a um estudo sobre o Estado Democrático de Direito em diálogo com N. Luhmann e J. Habermas -, M. Neves afasta-se enfaticamente da tradição teórico-social brasileira que atribui a motivos antropológico-culturais os problemas que seriam, segundo essa tradição, peculiares ao país:

${ }^{66}$ Conferir, por exemplo: NEVES, Marcelo. Entre Hidra e Hércules: princípios e regras constitucionais como diferença paradoxal do sistema jurídico. 2. ed. São Paulo: WMF Martins Fontes, 2014. p. 189 e ss. 
Não se trata aqui de um problema estritamente antropológico-cultural do Brasil $^{67}$. Ele é indissociável do próprio tipo de relações sociais em que se encontra envolvido o Estado na modernidade periférica em geral, ultrapassando os limites de "antropologias nacionais" e correspondentes singularidades culturais. ${ }^{68}$

É interessante observar que, em trabalho de 2015, criticando texto de Jessé Souza que houvera tomado sua obra como objeto de análise ${ }^{69}$, Marcelo Neves procura resgatar esse afastamento em relação ao que J. Souza rotula como "postura culturalista":

Em um rasgo de desinformação e irresponsabilidade acadêmicas, Jessé Souza pretende enquadrar-me entre os "intérpretes do Brasil" na busca de uma singularidade brasileira ou latino-americana, atribuindo a mim e também a Niklas Luhmann uma postura "culturalista" e imputando-nos, em uma deformação gritante de nossas obras, "racismo mal disfarçado em 'culturalismo' das teorias da modernização tradicional - que substancializam e 'essencializam' supostas heranças culturais como até cem anos atrás se 'essencializavam' supostas diferenças raciais" [...]. Além disso, apõe à minha obra apocrifamente a expressão "sociedades avançadas" [...]. [...] Minha obra é inundada de passagens em que rejeito a noção de singularidade da experiência brasileira ou latinoamericana (o Brasil não existe como sociedade no modelo da teoria dos sistemas), ainda mais se isso implica uma noção de unidade ou herança cultural [...] ou a noção de "sociedades avançadas" levada a cabo pelas teorias "clássicas" da modernização [...]. Antes estudo problemas de assimetrias estruturais na sociedade mundial (moderna), que são dinâmicas e contingentes nos termos da teoria dos sistemas, não tendo nada de "essencial". ${ }^{70}$

Essa autodefesa de $M$. Neves sustenta-se, certamente, à luz de alguns de seus textos, como de resto fica provado pelo trecho imediatamente acima extraído de "Entre Têmis e Leviatã”. Mas, em “A constitucionalização simbólica”, essa ruptura com a teoria social brasileira de orientação culturalista não é de nenhum modo óbvia. As causas ou os fatores de correlação que ocasionam a "realidade constitucional desjuridificante" não ficam claros, e tanto as epígrafes tomadas de empréstimo a Sérgio Buarque de Holanda e a Raymundo Faoro ${ }^{71}$, quanto a

\footnotetext{
${ }^{67}$ Neste ponto, M. Neves refere-se, em nota de rodapé, a Gilberto Freyre, Sérgio Buarque de Holanda, Raymundo Faoro e Nestor Duarte. Conferir NEVES, Marcelo. Entre Têmis e Leviatã: uma relação difícil: o Estado Democrático de Direito a partir e além de Luhmann e Habermas. São Paulo: Martins Fontes, 2006. p. 247, nota 74.

${ }^{68}$ NEVES, Marcelo. Entre Têmis e Leviatã: uma relação difícil: o Estado Democrático de Direito a partir e além de Luhmann e Habermas. São Paulo: Martins Fontes, 2006. p. 247-248.

${ }^{69}$ SOUZA, Jessé. Niklas Luhmann, Marcelo Neves e o "culturalismo cibernético" da moderna teoria sistêmica. In: DUTRA, Roberto; BACHUR, João Paulo (orgs.). Dossiê Niklas Luhmann. Belo Horizonte: UFMG, p. 149-182, 2013.

${ }^{70}$ NEVES, Marcelo. Ideias em outro lugar? Constituição liberal e codificação do direito privado na virada do século XIX para o século XX no Brasil. Revista Brasileira de Ciências Sociais, v. 30, n. 88, jun. 2015. p. 1920, nota 6.
}

${ }^{71}$ NEVES, Marcelo. A constitucionalização simbólica. São Paulo: Martins Fontes, 2007. p. IX. 
repetição insistente da expressão "donos do poder", colocam em xeque a suposta perenidade desse autoproclamado distanciamento.

Como quer que seja, para além da arquitetônica estrita de “A constitucionalização simbólica", M. Neves constata que os problemas da "realidade constitucional" brasileira precisam ser situados, por um lado, em um horizonte estrutural e, por outro, em uma teia de relações que ultrapassa o cenário nacional.

Quanto a esses dois pontos - questões estruturais e influência externa, extranacional, na determinação das configurações possíveis no interior dos países da "modernidade periférica” -, o tratamento dado a eles por M. Neves em outro de seus livros, "Transconstitucionalismo" destinado a pensar os entrelaçamentos heterárquicos entre ordens jurídicas plurais em torno de problemas de direitos e garantias fundamentais e de controle do poder -, não deixa margem para dúvidas:

Analogamente, a relação dos regimes privados para com as formas de direito dos países periféricos afasta-se, com certa regularidade, do modelo transconstitucional. A corrupção sistemática das formas de direito dos Estados frágeis mediante as autorregulações privadas no plano transnacional, em benefício das grandes empresas multinacionais, não é algo a ser considerado apenas na perspectiva de uma crítica de esquerda ao capitalismo. Essa questão deve ser levada a sério também com vista às exigências de reconhecimento ou fortificação das autonomias discursivas das esferas plurais da sociedade mundial. As ordens jurídicas privadas transnacionais, enquanto "direito como meio" da economia, desenvolvem um tipo de racionalidade instrumental no âmbito jurídico, conforme a qual todas as pretensões normativas emergentes das formas de direito dos países mais fracos tendem a ser julgadas como perturbações para a dinâmica de sua expansão. Daí por que aquelas ordens propendem a desprezar estas pretensões com efeitos destrutivos sobre as respectivas formas de direito. ${ }^{72}$

Essa propensão expansiva de efeitos destrutivos não se resume ao uso instrumental do direito pelo sistema econômico. Também internamente ao sistema jurídico tomado como sistema segmentado territorialmente na sociedade hipercomplexa mundial, é possível identificar comportamentos destrutivos em face de pretensões de autonomia do direito no contexto da “modernidade periférica":

as ordens jurídicas e culturas jurídicas dos Estados fortes no contexto da sociedade mundial atuam destrutivamente em relação ao desenvolvimento de formas de direito de outros Estados. Nesse particular, destaca-se o problema da opressão "pós-colonial" ou "neocolonial" de experiências positivas com o direito nos países periféricos. Quando surgem formas desviantes de relações jurídicas concernentes ao mercado, à distribuição do poder, à identidade cultural, à

\footnotetext{
${ }^{72}$ NEVES, Marcelo. Transconstitucionalismo. São Paulo: WMF Martins, 2009. p. 282-283.
} 
educação etc., medidas de intervenção são frequentemente propostas e executadas, para que a compreensão jurídica do Estado dominante passe novamente a valer. ${ }^{73}$

Portanto:

as formas estatais de direito das "grandes potências" permanecem intocáveis perante o direito internacional público e contra esse imunizadas. Também essas formas jurídicas comportam-se opressivamente em relação às formas de direito dos países fracos na constelação internacional. Isso é verificável sobretudo quando esses tomam medidas desviantes na direção de transformações sociais. Da mesma maneira, as ordens jurídicas transnacionais instrumentalizadas pelas grandes empresas atuam destrutivamente sobre as formas de direito dos chamados países em desenvolvimento e das comunidades locais não estatais. ${ }^{74}$

Se é verdade que a atuação destrutiva sobre as "formas de direito" dos países periféricos advém tanto da instrumentalização do direito por grandes empresas multinacionais quanto da opressão perpetrada por países centrais, não é menos verdade que o sistema econômico assume a dianteira no cenário mundial, inclusive sobrepondo-se às expectativas de autonomia dos sistemas jurídico e político dos países da "modernidade central”:

As formas de direito do contrato e da propriedade afirmam-se expansivamente contras as formas de direito do meio ambiente e da inclusão. E, no contexto dos novos desenvolvimentos da sociedade mundial, as formas do direito econômico, determinadas funcionalmente, apresentam-se cada vez mais fortes do que as formas do direito político do Estado constitucional, territorialmente condicionadas. ${ }^{75}$

Em outros termos:

as assimetrias das formas de direito conduzem à repressão das frágeis formas jurídicas do contrato do direito ambiental, do direito social e dos direitos humanos, permanentemente reprimidas pelas fortes formas de direito do contrato, da propriedade, do mercado e do poder. ${ }^{76}$

Como se procurou apontar, os elementos da realidade constitucional e do público ativo ocupam um lugar axial para a compreensão e para a crítica da tese da "constitucionalização simbólica". Em “A constitucionalização simbólica”, a realidade constitucional aparecia expressamente como um obstáculo interno aos países da "modernidade periférica", obstáculo mais bem traduzido na expressão "realidade constitucional desjuridificante”. É dessa realidade -

\footnotetext{
${ }_{73}^{73}$ NEVES, Marcelo. Transconstitucionalismo. São Paulo: WMF Martins, 2009. p. 282.

74 Ibidem. p. 285-286.

${ }^{75}$ Ibidem. p. 284-285.

76 Ibidem. p. 286.
} 
e da correspondente falta de um público ativo - que resulta o fenômemo da alopoiese do direito, da desdiferenciação entre sistema jurídico e ambiente com a correlata incapacidade do direito de reproduzir-se autonomamente, sendo seu código binário preferencial sobredeterminado por códigos binários outros, destacando-se o código poder/não-poder do sistema político.

Em “Entre Têmis e Leviatã" e, principalmente, em "Transconstitucionalismo", aflora a percepção dos determinantes externos que se impõem frente às pretensões de autonomia operativa do sistema jurídico dos países periféricos. Ou seja, é relativizada a relevância da "realidade constitucional" interna em favor das influências oriundas da ordem externa aos Estados periféricos - ordem externa essa formada por outros Estados, situados na "modernidade central”, e por grandes empresas transnacionais. São essas influências que intervêm contra "experiências positivas com o direito nos países periféricos", experiências que podem significar “medidas desviantes na direção de transformações sociais”. Não é difícil perceber a mudança de panorama: não se afirma mais uma impossibilidade de transformação social pelo direito devido a uma "realidade constitucional desjuridificante"; afirma-se que experiências positivas com o direito, de fato existentes, em prol de transformações sociais, são barradas pela atuação destrutiva de Estados centrais e de empresas trans ou multinacionais.

Além disso, em “A constitucionalização simbólica” não fica evidente a que exatamente se refere a expressão "realidade constitucional desjuridificante". Já em "Entre Têmis e Leviatã" e em "Transconstitucionalismo" essa realidade é descrita estruturalmente, não antropológica ou culturalmente. Ao mesmo tempo, não obstante arraigado na teia conceitual da teoria sistêmica, Marcelo Neves reconhece cada vez mais a posição de relevo do sistema econômico global ${ }^{77}$, capaz de sobrepor-se até mesmo às expectativas de autonomia sistêmica do direito e da política nos Estados centrais.

Se, porém, no que tange à realidade constitucional tais mudanças são dignas de nota, alterações semelhantes não se verificam no que diz respeito ao público ativo. Marcelo Neves continuará sustentando o diagnóstico da falta de uma esfera pública plural fundada na universalidade da cidadania como fator de definição da "modernidade periférica", especialmente no caso do Brasil:

Evidentemente, a experiência brasileira marca-se por formas de instrumentalização política, econômica e relacional de mecanismos jurídicos,

\footnotetext{
77 Esse reconhecimento não estava de todo ausente em "A constitucionalização simbólica”, mas não recebia ali o acento que recebe nos escritos posteriores. Conferir, por exemplo: NEVES, Marcelo. A constitucionalização simbólica. São Paulo: Martins Fontes, 2007. p. 200.
} 
apontando no sentido inverso à indisponibilidade do direito. Há uma forte tendência a desrespeitar o modelo procedimental previsto no texto da Constituição, de acordo com conformações concretas de poder, conjunturas econômicas específicas e códigos relacionais. Isso está associado à persistência de privilégios e "exclusões" que obstaculizam a construção de uma esfera pública universalista como espaço de comunicação de cidadãos iguais. ${ }^{78}$

Mas mesmo aquelas mudanças de concepção referentes à realidade constitucional não podem ser superdimensionadas, pois, lidas mais atentamente, também elas não ultrapassam o quadro delimitado em "A constitucionalização simbólica”. No limite, realidade constitucional, ainda que reinterpretada, e público ativo - ou, em outras palavras, falta de diferenciação funcional adequada e de uma esfera pública plural baseada na generalização da cidadania permanecem os elementos decisivos:

Essas considerações sobre os obstáculos à realização do Estado Democrático de Direito na modernidade periférica devem afastar a ideia equivocada de uma legalidade rígida em face dos problemas sociais, assim como o mito de um Estado forte diante de uma sociedade frágil. Nos dois casos, parte-se da concepção de que o problema reside primariamente na inadequada heterorreferência. $\mathrm{Na}$ verdade, trata-se antes de fragilidade do Estado perante as pressões de uma "sociedade" desestruturada pela insuficiente diferenciação funcional e a ausência de uma esfera pública pluralista, fundada na universalidade da cidadania. ${ }^{79}$

\section{CONCLUSÃO}

Conforme enunciado na introdução do presente artigo, o objetivo das páginas anteriores era resgatar os elementos que compõem a arquitetura conceitual $d a$ tese da "constitucionalização simbólica" e explicitar em que sentido esse conceito-tese contém internamente contradições que o tornam insustentável - contradições que se agudizam à medida que $M$. Neves avança em suas reflexões, inclusive para além do tema específico da “constitucionalização simbólica".

Certamente, também como enunciado na introdução, a crítica aqui esboçada não se justifica senão pela relevância que a tese da "constitucionalização simbólica" possui no horizonte da discussão teórico-constitucional brasileira e, mais ainda, pela profundidade e pelo rigor que a tal tese subjazem. É essa profundidade e esse rigor que tornam extremamente

\footnotetext{
${ }^{78}$ NEVES, Marcelo. Entre Têmis e Leviatã: uma relação difícil: o Estado Democrático de Direito a partir e além de Luhmann e Habermas. São Paulo: Martins Fontes, 2006. p. 246.

${ }^{79}$ Ibidem. p. 243-244.
} 
ISSN 1981-3694

(DOI): $10.5902 / 1981369424821$

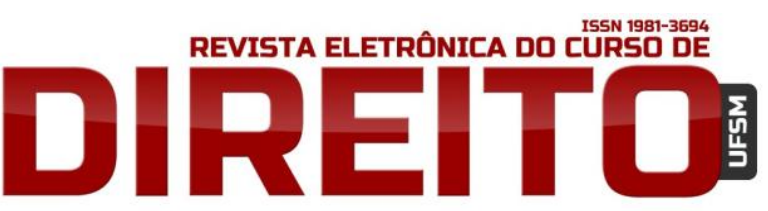

PARA UMA CRÍTICA À TESE DA CONSTITUCIONALIZAÇÃO SIMBÓLICA

DAVID FRANCISCO LOPES GOMES

profícuo um debate crítico como este aqui iniciado. Este debate, por suposto, não se perfaz sem que, para além da crítica à tese da "constitucionalização simbólica", seja oferecido um modelo explicativo alternativo para os problemas que ela identifica e sobre os quais ela se debruça.

A apresentação desse modelo alternativo, todavia, pretendendo fazer frente à tese da “constitucionalização simbólica”, precisa esforçar-se para oferecer ao menos profundidade e rigor semelhantes, o que não se alcança sem uma argumentação extensa, detalhada e cautelosa. Por isso mesmo, o trato desse modelo alternativo, dessa visada teórica distinta, não cabe nos limites deste artigo, sendo projetado para outra ocasião.

\section{REFERÊNCIAS}

CARVALHO NETTO, Menelick. Apresentação. In: MÜLLER, Friedrich. Legitimidade como conflito concreto do direito positivo. Cadernos da Escola do Legislativo, Belo Horizonte, 5 (9), p. 7-12, jul./dez. 1999.

CATTONI DE OLIVEIRA, Marcelo Andrade. Teoria da Constituição. Belo Horizonte: Initia Via, 2012.

GOMES, David F. L. Gomes. A Constituição de 1824 e o problema da Modernidade: o conceito moderno de Constituição, a história constitucional brasileira e a teoria da Constituição no Brasil. Belo Horizonte: UFMG, 2016. Tese (doutorado) - Programa de Pós-Graduação em Direito, Universidade Federal de Minas Gerais, 2016.

HÄBERLE, Peter. Hermenêutica constitucional: a sociedade aberta dos intérpretes da constituição: contribuição para a interpretação pluralista e procedimental da constituição. Trad. Gilmar Ferreira Mendes. Porto Alegre: Sergio Antonio Fabris Editor, 1997.

HABERMAS, Jürgen. Facticidad y validez - Sobre el derecho y el Estado democrático de derecho en términos de teoria del discurso. Trad. Manuel Jiménez Redondo. 4. ed. Madrid: Trotta, 2005.

LOEWENSTEIN, Karl. Teoria de la Constitución. Trad. Alfredo Gallego Anabitarte. Barcelona: Ariel, 1976.

LUA NOVA. Lua Nova: Revista de Cultura Política. v. 84 - Após a Participação. São Paulo: CEDEC, 2011.

MÜLLER, Friedrich. Teoria estruturante do direito. Trad. Peter Naumann e Eurides Avance de Souza. São Paulo: Revista dos Tribunais, 2008.

NEVES, Marcelo. A constitucionalização simbólica. São Paulo: Martins Fontes, 2007. 
ISSN 1981-3694

(DOI): $10.5902 / 1981369424821$

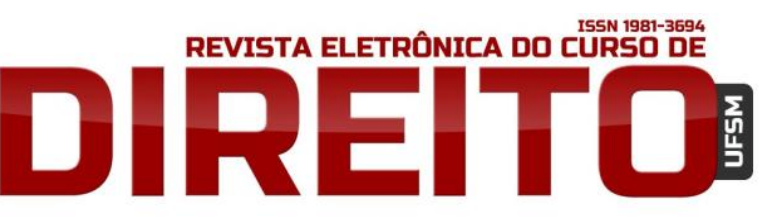

PARA UMA CRÍTICA À TESE DA CONSTITUCIONALIZAÇÃO SIMBÓLICA

DAVID FRANCISCO LOPES GOMES

NEVES, Marcelo. Entre Hidra e Hércules: princípios e regras constitucionais como diferença paradoxal do sistema jurídico. 2. ed. São Paulo: WMF Martins Fontes, 2014.

NEVES, Marcelo. Entre Têmis e Leviatã: uma relação difícil: o Estado Democrático de Direito a partir e além de Luhmann e Habermas. São Paulo: Martins Fontes, 2006.

NEVES, Marcelo. Ideias em outro lugar? Constituição liberal e codificação do direito privado na virada do século XIX para o século XX no Brasil. Revista Brasileira de Ciências Sociais, v. 30, n. 88, p. 5-27, jun. 2015.

NEVES, Marcelo. Transconstitucionalismo. São Paulo: WMF Martins, 2009.

REPOLÊS, Maria Fernanda Salcedo. Habermas e a Desobediência Civil. Belo Horizonte: Mandamentos, 2003.

SOUZA, Jessé. Niklas Luhmann, Marcelo Neves e o "culturalismo cibernético" da moderna teoria sistêmica. In: DUTRA, Roberto; BACHUR, João Paulo (orgs.). Dossiê Niklas Luhmann. Belo Horizonte: UFMG, p. 149-182, 2013.

Recebido em: 22/11/2016 / Revisões requeridas em: 13/06/2017 / Aprovado em: 20/06/2017

\section{COMO CITAR O ARTIGO (ABNT)}

GOMES, David Francisco Lopes. PARA UMA CRÍTICA À TESE DA CONSTITUCIONALIZAÇÃO SIMBÓLICA. Revista Eletrônica do Curso de Direito da UFSM, Santa Maria, RS, v. 12, n. 2, p. 442-471, ago. 2017. ISSN 1981-3694. Disponível em:

$<$ https://periodicos.ufsm.br/revistadireito/article/view/24821>. Acesso em: dia mês. ano.

doi:http://dx.doi.org/10.5902/1981369424821. 